\title{
Reflexões leninistas sobre o Estado e a luta das mulheres socialistas*
}

\section{Leninist reflections on State and the struggle of socialist women}

\author{
Leonardo Nogueira Alves*
}

\begin{abstract}
Resumo - Este trabalho objetiva apresentar algumas reflexões em torno da concepção de Lenin sobre Estado e situar sua percepção acerca das lutas e reivindicações das mulheres. Para isso, busca apresentar as condições históricas em que emergem tais concepções e sua centralidade na perspectiva revolucionária.

Palavras-chave: Estado; Lenin; feminismo socialista.
\end{abstract}

\begin{abstract}
This paper aims to present some reflections on Lenin's con-ception of State as well as to place his perception of women's struggle in context. For this, it seeks to present the historical conditions under which these concepts emerged and their centrality in the revolutionary perspective.
\end{abstract}

Keywords: State; Lenin; feminism.

\section{Introdução}

Meu canto se renova

E recomeço a busca

Dum país liberto

Duma vida limpa

E dum país justo.

Sophia de Mello ${ }^{1}$

Neste trabalho nos propomos a dialogar com a formulação de Lenin (2010) acerca do Estado, do ponto de vista da sua função e da necessidade de sua destruição. Também nos colocamos no desafio de apreender,

\footnotetext{
* Este artigo foi desenvolvido incialmente para a disciplina de teoria política contemporânea, ministrada pela professora Silene de Moraes Freire no PPGSS/UERJ. Posteriormente, alguns elementos foram aprofundados na nossa dissertação intitulada "Relações patriarcais de gênero e Serviço Social no Brasil" em fase de finalização.

** Mestrando do Programa de Pós-graduação em Serviço Social (PPGSS) da Universidade do Estado do Rio de Janeiro e bolsista da Fundação Carlos Chagas Filho de Amparo à Pesquisa do Estado do Rio de Janeiro - FAPERJ. Email: <leo.ssoufvjm@gmail.com>.
}

${ }^{1}$ MELLO, Sophia de. Essa gente. In: Antologia. Lisboa: Moraes Editores, 1970, p. 201. 


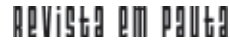

\} REFLEXÕES LENINISTAS SOBRE O ESTADO E A LUTA DAS MULHERES - ALVES, L. N. \}

DOI: $10.12957 /$ REP.2016.27841

a partir dos escritos de Lenin, a percepção dele acerca das relações de opressão a que as mulheres estão submetidas e o papel que cumpre à revolução para construir a igualdade entre homens e mulheres.

Lenin sempre se colocou no desafio teórico-político de construir uma abordagem acessível à classe trabalhadora e com desdobramentos na luta de classes. Reconhecer esta dimensão da sua obra é um imperativo para dialogar com este pensador/militante que vislumbra a necessidade e a possibilidade da "revolução socialista" em toda a sua trajetória.

As contribuições de Vladimir Ilitch Lenin foram primordiais no campo dos estudos sobre "teoria da organização política". Lukács (2012) reforça o pioneirismo de Lenin ao afirmar que por muito tempo ele foi o único líder e teórico a considerar o problema da organização. Na concepção desenvolvida por Lenin, o partido é instrumento político capaz de aglutinar os setores mais conscientes do proletariado de forma centralizada. Ou seja, o partido exerce uma função dirigente da classe operária. Lukács (2012) percebe que a centralidade da concepção de partido em Lenin consiste na sua função preparatória, ou seja, o partido precisa atuar de maneira intencional nas constrições da sociedade capitalista no intuito de acelerar a precipitação da ordem burguesa. Lukács (2012) destaca que na obra e na trajetória política de Lenin a concepção de organização está umbilicalmente ligada à perspectiva de revolução. Para Braz (2015, p. 11), Lenin "renovou teoricamente o debate sobre a revolução - e, nela, a questão da organização política do proletariado, a sua relação com o Estado -, acentuando a necessidade de criação de uma organização revolucionária disciplinada".

No decorrer deste breve texto apresentaremos uma caracterização do período histórico em que Lenin realiza a maior parte de suas reflexões, bem como a interlocução com o legado de Marx e Engels. Em seguida, caracterizaremos o Estado a partir das reflexões de Lenin, especialmente à luz da obra $O$ Estado e a revolução, mostrando os aspectos centrais desta formulação: o Estado como produto do antagonismo inconciliável entre classes, como necessidade e via para o proletariado tomar o poder e instaurar a ditadura do proletariado.

\section{Condições históricas e emergência da formulação de Lenin}

A passagem do século XIX para o século XX é marcada por inúmeras transformações políticas e econômicas. Lenin (2012) percebe que, neste momento, o capitalismo transitava para sua fase madura, intitulada fase imperialista. Nesse contexto, a classe trabalhadora buscava retomar os preceitos do internacionalismo com a construção da II Internacional Comunista.

Entre os adeptos do comunismo, esse momento foi marcado por uma possível "crise do marxismo", explicitada no objetivo de hegemonizar a organização dos trabalhadores pela via do reformismo/oportunismo ou 


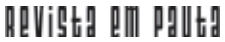

\} REFLEXÕES LENINISTAS SOBRE O ESTADO E A LUTA DAS MULHERES - ALVES, L. N. \}

DOI: $10.12957 /$ REP.2016.27841

pela via revolucionária da tomada do poder do Estado, conforme Chevallier (1973).

Embora tais perspectivas busquem inspiração nas formulações de Marx e Engels, elas são diametralmente divergentes. Lenin foi um dos responsáveis por formular uma interlocução profunda com o pensamento de Marx e Engels, retomando as experiências das lutas e da tomada do poder na Europa do século XIX, especialmente no que se refere à Comuna de Paris. Sobre esta, cabe ressaltar que, de acordo com Montaño e Duriguetto (2011, p. 230-231):

Em março de 1871, os operários franceses fazem uma revolução da capital, que ficou conhecida como Comuna de Paris. A burguesia e o exército foram expulsos pelos trabalhadores em armas. Um novo governo foi criado em torno da qual se agruparam principalmente os trabalhadores. [...] A experiência triunfou 72 dias, sendo os trabaIhadores massacrados pelo exército francês e alemão. Estima-se que de trinta a cinquenta mil trabalhadores foram mortos.

Desse modo, Lenin teve o desafio de compreender e explicar não só a pertinência da revolução nos textos clássicos de Marx e Engels, como também apreender as determinações da Rússia czarista, marcada por um regime autocrático e pela crescente pauperização do seu povo.

Ressalta-se que, já no início do século XX, a possibilidade da eclosão da I Guerra Mundial estava posta. Esta irrompe em 1914 e coloca em xeque as teses da Internacional Comunista, tendo em vista que inúmeros partidos da socialdemocracia apoiaram a guerra com o argumento de defender sua pátria. Nas palavras de Chevallier (1973, p. 362):

Rompe a guerra de 1914. [...]É um desastre para a Internacional. Em todos os países beligerantes, o grosso dos partidos declara pela defesa da pátria. O kautskismo, do nome do alemão Kautsky, que antes da guerra representava o marxismo ortodoxo e que condenava o oportunismo em teoria, mas sem romper praticamente com ele, conserva-se, em face dessa situação, na mesma política prudente: uma política de centro.

Esse contexto histórico é refletido por Lenin (2015) à luz das condições históricas e objetivas da Rússia. Lenin enfrentou o desafio constante de particularizar o universal e universalizar o particular. Dessa maneira, buscou compreender as determinações da Rússia é um passo fundamental para perceber as possibilidades e as vias históricas para a revolução.

A Rússia, se comparada aos demais países da Europa, vivenciava um contexto de atraso político-econômico com uma economia predominantemente agrícola. Contudo, havia contrastes importantes, como, por exemplo, as iniciativas de grandes indústrias do meio urbano que requisitavam força de trabalho daqueles que emigravam do campo. Esse processo foi essencial para a formação do operariado russo. 


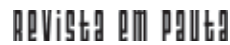

\} REFLEXÕES LENINISTAS SOBRE O ESTADO E A LUTA DAS MULHERES - ALVES, L. N. \}

DOI: $10.12957 /$ REP.2016.27841

Em meados da década de 1870, a Rússia estava sob um regime czarista, no qual o czar detinha o poder político e econômico. Uma espécie de monarquia autocrática. Tanto a nascente burguesia, quanto o crescente proletariado estavam insatisfeitos com esse regime. Focos de resistência e de lutas surgiam num contexto de aumento da repressão pelo czar.

Neste momento, a Rússia também passava por um período de "revolução agrícola", processo tímido no qual a terra se torna propriedade mercantil, ou seja, sua produção passa a integrar o mercado interno, numa perspectiva de produzir insumos para a manufatura que estava surgindo. O desenvolvimento da manufatura e da grande indústria era precário e dependia da relação com a França e, posteriormente, com a Alemanha.

A composição das classes sociais e suas frações também é um fator relevante para compreender a conjuntura da Rússia naquele período: pequenos burgueses e burguesia industrial, aristocracia agrária (bases dos czares), camponês médio e trabalhadores assalariados faziam parte da estrutura de classes daquele período.

A necessidade de construção de uma agenda democrática sintonizava as reivindicações de amplos setores da sociedade em oposição ao regime czarista. Tanto as reivindicações por direitos trabalhistas quanto a liberdade de mercado dialogavam no combate ao czar. Neste contexto, começam a surgir as experiências sindicais e os soviets (conselho dos operários), influenciados pela conjuntura da II Internacional.

Os desafios teóricos e políticos de Lenin se inseriram neste contexto, levando em conta as particularidades da Rússia e os ditames da conjuntura internacional. Para Chevallier (1973, p. 363),

Criar na Rússia autocrática um partido marxista, vanguarda da classe operária, determinar-lhe um programa preciso e uma tática eficaz, eliminar impiedosamente qualquer 'desvio' em relação ao marxismo 'autêntico', tal foi, do princípio ao fim, a tarefa de Lenin. [...] 'Sem teoria revolucionária, não há ação revolucionária' [Lenin apud Chevallier]. A teoria tornava possível a ação, mas essa fazia com que a teoria progredisse, transformando-a.

Estes desafios teóricos e políticos de Lenin se materializaram na construção do partido socialdemocrata russo e da II Internacional. Naquele momento, os soviets espalhavam sua influência e os sindicatos começavam a ter influências anarquistas. Lenin (2015) criticou duramente o espontaneísmo e o economicismo das ideias anarquistas. Cabe ressaltar que sua atuação no partido socialdemocrata russo (o qual, ao se constituir enquanto maioria política, recebe o nome de partido bolchevique) é marcada por uma vitória interna e pela derrota externa nos rumos da II Internacional.

A situação política da Rússia se agrava com a greve geral dos operários entre 1905 e 1907. A recepção violenta do czar aos manifestantes grevistas foi decisiva para disseminar a revolta do povo russo. De 1905 a 
1917 inúmeras lutas foram travadas contra o regime czarista, nas quais a atuação dos bolcheviques é essencial. Simultaneamente, eles combinaram a disputa institucional e o vínculo com as massas trabalhadoras e suas organizações clandestinas.

A entrada da Rússia na I Guerra Mundial agrava as contradições de um país agrário e marcado pelo pauperismo da população. Em abril de 1917 Lenin escreveu as Teses de Abril, contribuindo para a formulação tática deste período. De acordo com Chevallier (1973, p. 366),

Lenin baseia sua argumentação no fato de que o poder, embrionário, mas crescente, dos soviets, isto é, das comissões revolucionárias de deputados operários e soldados 'é do mesmo tipo que a Comuna de Paris, de $1871^{\prime}$. A todos que resistem às teses de abril, acusa de não quererem ver a evidente verdade de que na medida em que eles são o poder, existe na Rússia 'um Estado do tipo da Comuna de Paris'².

Liderados por Lenin, os bolcheviques conseguiram ascender ao poder com a percepção de que era necessário propagandear a seguinte frase: "Todo poder aos soviets". A Revolução Russa irrompe logo após Lenin escrever as Teses de Abril e O Estado e a revolução. Estes textos são cruciais para compreender a concepção de Lenin acerca do Estado. Vejamos a seguir alguns elementos centrais em sua formulação.

\section{A formulação leninista de Estado}

A compreensão de Vladimir Lenin acerca do Estado está explícita no texto escrito às vésperas da Revolução Russa (entre agosto e setembro de 1917), intitulado O Estado e a revolução. Lenin (2010) destacou, nesta obra, três elementos fundamentais: a tomada violenta do poder, a ditadura do proletariado e a ideia do definhamento do Estado. Tendo em vista estes três elementos, é necessário fazer duas ressalvas importantes. Primeiro, o Estado não é uma "coisa", mas uma relação social; segundo, compreender esta formulação implica localizar o seu contexto histórico no quadro da possibilidade concreta da revolução.

Lenin (2010) procurou absorver o pensamento de Marx e Engels construindo uma estratégia para a tomada do poder político do Estado. Há, neste autor, uma crítica visceral tanto ao reformismo quanto ao esquerdismo, tendo em vista que a questão central para ele é o poder. É com essas ressalvas que podemos apreender o significado teórico e político da elaboração de Lenin.

Para o líder revolucionário, o Estado (enquanto relação) é um produto do antagonismo inconciliável entre as classes sociais. Esta afirmação

${ }^{2}$ Citações entre aspas são referências a textos do próprio Lenin, de acordo com Chevallier (1973). 
central se vale do leito histórico de Marx e Engels e da tradição do marxismo, que demarca sua incompatibilidade com a racionalidade burguesa. Em suas palavras:

O Estado é o produto e a manifestação do antagonismo inconciliável das classes. O Estado aparece onde e na medida em que os antagonismos de classes não podem objetivamente ser conciliados. E, reciprocamente, a existência do Estado prova que as contradições de classes são inconciliáveis. (LENIN, 2010, p. 27).

O Estado é produto da sociedade numa determinada fase de desenvolvimento das forças produtivas, onde há apropriação privada do excedente. Em suma, o Estado é um modo de exercício do poder de uma classe sobre a outra. Essa análise está embasada nas afirmações de Marx e Engels (2010) no Manifesto do Partido Comunista, no qual os autores apontam o Estado como aparelho de dominação da burguesia.

Lenin também percebeu que este exercício do poder é realizado por meio da organização da força armada; em suas palavras, pelos "destacamentos de homens armados" (LENIN, 2010, p. 29), ou seja, a polícia e o exército permanente são essenciais para garantir o poder da burguesia sobre o Estado. Por isso, percebe-se que a construção de força própria da classe trabalhadora é uma condição essencial para a tomada violenta do poder do Estado. Este processo deve ser mediado pela construção de destacamentos armados a serviço dos interesses dos trabalhadores. Para Lenin (2010, p. $30)$, "toda grande revolução põe diante de nós em plena evidência e na escala da ação das massas, ou seja, a questão das relações entre os destacamentos separados de homens armados e a organização espontânea da população em armas". Chevallier (1973, p. 372 - grifos no original), por sua vez, ressalta que:

O proletariado, depois de se apoderar da máquina do Estado, transforma-se em classe dominante; estabelece a sua ditadura, ou seja, um poder que não partilha com pessoa alguma. O Estado, força especial de repressão, organização especial da violência, torna-se proletário em vez de ser burguês. [...] A mesma ditadura permitirá ao proletariado transformar todos os meios de produção em propriedade do Estado, e organizar todas as massas trabalhadoras e exploradas em vista do novo regime econômico.

Além destas caracterizações, é necessário destacar um elemento essencial para concepção de Estado e de revolução em Lenin (2010). Tendo em vista que ele percebeu o Estado como relação e não como coisa, Lenin (2010) se valeu da seguinte passagem de Engels (2010, p. 218):

[...] o Estado não tem existido eternamente. Houve sociedades que se organizaram sem ele [...] Ao chegar certa fase do desenvolvimento 
econômico, que estava necessariamente ligada à divisão da sociedade em classes, essa divisão tornou o Estado uma necessidade. [...] com o desaparecimento das classes, desaparecerá inevitavelmente o Estado. A sociedade, reorganizando de uma forma nova a produção, na base de uma associação livre de produtores iguais, mandará toda a máquina do Estado para o lugar que The há de corresponder: o museu de antiguidades, ao lado da roca de fiar e do machado de bronze.

Dessa forma, Lenin (2010) concordou com Engels e, ao perceber que o Estado tem um vínculo umbilical com as classes sociais, destaca que, a partir da destruição das relações de classe, o Estado perde seu sentido. Esse processo só pode ser viável com a "ditadura do proletariado", que consiste numa fase em que, após a tomada do poder, o proletariado, organizado enquanto força dirigente, toma o poder da burguesia e com isso cria as condições para o fim das classes sociais, possibilitando o definhamento do Estado.

O Estado não é destruído, ele apenas perde o seu sentido e a sua necessidade, ou seja, nesta fase sem dominação de classes não há necessidade de um Estado. Lenin (2010, p. 41) ressalta que, "a substituição do Estado burguês pelo Estado proletário não é possível sem uma revolução violenta. A abolição do Estado proletário, isto é, a abolição de todo e qualquer Estado, só é possível pelo definhamento".

Tendo em vista que o definhamento do Estado só é possível com a "ditadura do proletariado", Lenin (2010) ressaltou que, sob a ordem burguesa, a democracia é uma farsa, pois é expressão de um regime de liberdade apenas para a minoria. A "ditadura do proletariado" é a possibilidade de uma democracia para os pobres, ou seja, para a maioria, onde haveria rígidas restrições à liberdade dos opressores. Ao tomar o poder do Estado, o proletariado só tem um interesse: levar até o fim a destruição das classes e tornar possível o definhamento do Estado. Nas palavras de Lenin (2010, p. 44-45),

[...] os trabalhadores só têm necessidade do Estado para quebrar a resistência dos exploradores [...] o proletariado é a única classe revolucionária até o fim capaz de unir todos os trabalhadores e todos os explorados na luta contra a burguesia, a fim de suplantar definitivamente.

Este processo não é simples e muito menos rápido. Para Lenin (2010), a expressão definhamento explicita que este é um processo lento e gradativo. A "ditadura do proletariado" seria esse momento de transição do capitalismo para o comunismo, no qual ainda há a necessidade de repressão dos exploradores.

É importante explicitar que, de acordo com Lenin (2010), o Estado nesse contexto não teria as mesmas características do Estado burguês, pois este visa à construção da democracia para a maioria da população e vislumbra o desmonte da burocracia que o torna possível e necessário. 


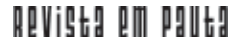

\} REFLEXÕES LENINISTAS SOBRE O ESTADO E A LUTA DAS MULHERES - ALVES, L. N. \}

DOI: $10.12957 /$ REP.2016.27841

Opera-se, portanto, uma profunda alteração da base econômica (forças produtivas) com a socialização da riqueza produzida e dos meios de produção. Além disso, essa transformação acontece também na construção de valores e formas de solidariedade que existem na sociedade e que devem ser estimuladas, recuperadas e fortalecidas para romperam com os estigmas da sociedade capitalista. Ou seja, nessa transição, homens e mulheres devem construir novas formas de interação.

Nesse processo, é possível vivenciar concretamente o "Reino da Liberdade", o início da história da humanidade. Assim, percebe-se o comunismo como uma etapa superior da história da humanidade. De fato, onde ela se inicia, supera-se a "pré-história da humanidade".

A superação da ordem burguesa coloca desafios no âmbito da produção e da reprodução social. É neste sentido que Lenin (2010) se sensibilizou com a percepção de que a construção dos novos homens e das novas mulheres é um imperativo para superação desta ordem. Desse modo, a superação da pré-história da humanidade está associada às transformações das relações patriarcais de gênero que subordinam as mulheres em relação aos homens.

No próximo item, faremos alguns apontamentos acerca das formulações da tradição marxista e das militantes feministas socialistas em busca da superação das desigualdades decorrentes das relações patriarcais de gênero.

\section{Lenin e a luta das mulheres}

Liberdade e igualdade para o sexo oprimido (LENIN, 1919c).

\subsection{Breve incursão histórica}

Há indícios de que as primeiras experiências organizativas das mulheres podem ser localizadas no curso da luta pela Independência dos Estados Unidos e da Revolução Francesa. Entretanto, é na França que as mulheres iniciam sua participação de forma mais efetiva. Para Gurgel (2009), foi no contexto da Revolução Francesa que as mulheres se colocaram como sujeito político pela primeira vez na história da humanidade. Nesse processo, inúmeras mulheres lutaram, foram guilhotinadas, reclamaram acesso à educação, à carreira militar etc. Alves e Pitanguy (1985, p. 32) também ressaltam que "é neste momento histórico que o feminismo adquire características de uma prática de ação política organizada".

Gurgel (2009, p. 9 - grifos no original), ao se referir à atuação das mulheres na Europa durante o período da Revolução Francesa, diz que:

[...] em quase meio século, as mulheres realizaram ações radicais de combate a sua exclusão da soberaneidade popular, inaugurada com a sociedade moderna que se propôs a eliminar todo tipo de desigualdade já que insurge com o lema da igualdade, liberdade e fraternidade. 
Entretanto, ainda de acordo com Gurgel (2010), a organização das mulheres e suas pautas de reinvindicações, especialmente a ampliação da participação política e dos direitos civis, não foram bem aceitas pelos dirigentes da Revolução Francesa. Dentre os impactos dessa relação houve a proibição das reuniões do clube de mulheres em 1793 e a perseguição a muitas mulheres, levando algumas à guilhotina.

Da Revolução Francesa até a segunda metade do século XIX, a luta das mulheres pela igualdade tornou-se central. Neste período, temos a primeira iniciativa de articulação da luta das mulheres com a luta dos operários. Pioneira nesse sentido, Flora Tristan apud Gurgel (2009), no livro União operária, ressalta a necessidade de articulação da luta feminista com a luta de classe. Contudo, no próprio movimento de trabalhadores havia resistência às reivindicações das mulheres. De acordo com Gurgel (2009, p. 11):

Apesar das mulheres contarem com o apoio do movimento dos trabalhadores na maioria de suas reinvindicações, foi particularmente, com relação ao direito ao trabalho que houve maior resistência. Inclusive em 1866, no congresso da Internacional dos Trabalhadores os delegados foram contra ao trabalho feminino. Esta decisão provocou reação imediata das mulheres socialistas e de seus aliados que intensificaram as manifestações públicas e fundaram a primeira associação feminista, chamada Liga das Mulheres, em 1868.

A autora ressalva que esta tensão perdurou até a Comuna de Paris, quando a centralidade da luta geral dos trabalhadores toma a dianteira das reivindicações pela igualdade de gênero. Desse modo, a organização mais contundente das mulheres direcionava-se às primeiras experiências socialistas e à luta das trabalhadoras vinculadas às organizações socialistas/ comunistas.

No que se refere à passagem do século XIX para o século XX, Alves e Pintaguy (1985) ressaltam que a luta do movimento operário tinha dois grandes focos: a luta pela melhoria das condições de trabalho e a luta pelos direitos da cidadania, da qual decorre a luta pelo voto universal. Contudo, as autoras resgatam que, na luta pelo sufrágio universal, não se incluía o direito de voto das mulheres. Importante dizer que, de acordo com Gurgel (2009), no contexto histórico da luta sufragista ocorria o processo de consolidação do capitalismo e da crescente industrialização. Com isso, houve inúmeros impactos na vida das mulheres; dentre eles, salienta-se o fato de que elas eram cada vez mais requisitadas para o mundo do trabalho, contudo, sem nenhuma possibilidade de acesso a direitos civis e políticos.

Diante deste contexto de invisibilidade, as mulheres travaram lutas mundo afora pelo sufrágio feminino. Essa bandeira unificou não apenas as mulheres socialistas, mas tornou-se uma bandeira de reinvindicação geral, inclusive das mulheres burguesas. 


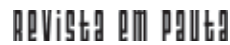

\} REFLEXÕES LENINISTAS SOBRE O ESTADO E A LUTA DAS MULHERES - ALVES, L. N. \}

DOI: $10.12957 /$ REP.2016.27841

É importante demarcar que, mesmo diante de uma pauta que tem como pressuposto a unidade na luta das mulheres socialistas e burguesas, havia divergências explícitas no que diz respeito à concepção e ao objetivo da conquista do voto universal. Para isso, é necessário relembrar o pronunciamento de Clara Zetkin na $4^{\circ}$ Conferência de Mulheres Socialistas ${ }^{3}$.

Clara Eissner Zetkin (1857-1933) nasceu na Alemanha e desenvolveu um grande trabalho à frente do movimento de mulheres socialistas; paralelamente, ela participava ativamente do Partido da Social-Democracia Alemã (SPD). Ficou conhecida mundialmente por militar pelo direito de voto das mulheres, tendo, inclusive, uma atuação de destaque na conferência que instituiu o Dia Internacional das Mulheres, além de atuar como dirigente das mulheres na II Internacional Comunista. Rompeu com o SPD durante a I Guerra Mundial, uma vez que o partido votou favoravelmente à participação da Alemanha na guerra. De acordo com Zetkin (2010, p. 167),

[...] no tema do sufrágio feminino existe uma clara linha divisória entre nós e o movimento de mulheres burguesas. Nossa concepção é que a reivindicação do sufrágio feminino deriva, em primeiro lugar, das consequências do sistema de produção capitalista. As mulheres burguesas, ainda hoje, reclamam sufrágio como um direito natural, como fez a filosofia especulativa do final do século 18 e começo do século 19. Nós [...] reclamamos o sufrágio feminino como um direito social [...] devido à transformação que o sistema capitalista exerceu na vida econômica e, inclusive na mentalidade das mulheres [...].

Vale a pena destacar que, diante das divergências entre burguesas e socialistas, Clara Zetkin e suas companheiras, mesmo não vendo a possibilidade de unidade estratégica, viam a possibilidade de diálogo para atingirem o sufrágio feminino. Elas tinham "consciência que os direitos reivindicados pelas burguesas também eram úteis às operárias, em especial na luta pelo direito ao voto [...] as mulheres proletárias, [e] nesta demanda concreta, podiam marchar ao lado das burguesas, ainda que não lutassem juntas" (GONZÁLEZ, 2010, p. 64). Afora isso, a inserção das mulheres nos partidos socialistas impulsionou outras lutas além do sufrágio feminino, dentre estas, o acesso à educação, o direito ao divórcio, a socialização de tarefas domésticas etc.

\subsection{Mulheres, Estado e revolução ${ }^{4}$}

A relação entre feminismo e socialismo demonstra, simultaneamente, a firme atuação das mulheres socialistas e a significativa inflexão dos partidos comunistas às pautas de reivindicação das mulheres.

\footnotetext{
${ }^{3}$ Realizada no ano de 1906 , em Mannhein.

${ }^{4}$ Parafraseando Wendy Goldman (2014).
} 


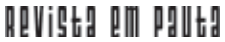

\} REFLEXÕES LENINISTAS SOBRE O ESTADO E A LUTA DAS MULHERES - ALVES, L. N. \}

DOI: $10.12957 /$ REP.2016.27841

Deflagrada a Revolução Russa, as trabalhadoras organizadas vislumbravam a possibilidade de colocar em xeque a opressão que as mulheres vivenciavam, associadamente à transformação da sociabilidade burguesa. Goldman (2014) ressalta que, um ano após a tomada do poder pelos revolucionários, foi ratificado um novo código sobre casamento e família, que na prática ampliava os direitos das mulheres, visando promover sua autonomia em relação aos homens.

Uma questão essencial que se coloca na transição comunista é a conservação ou extinção da família. Já nos primeiros meses da Revolução Russa, em 18 de dezembro de 1917, um decreto dos "comissários do povo" facilitou as regras do divórcio, dando às famílias proletárias a possibilidade da separação. Para Kollontai (1982), a família na sociedade russa representava as ruínas de um passado em permanente destruição que a própria dinâmica do capitalismo (industrialização, urbanização) provocava. Para ela, a emergência e o crescimento do trabalho assalariado das mulheres contribuíam para o ostracismo dos papéis que homem e mulheres estabeleciam para a reprodução familiar. Neste aspecto, a principal preocupação de Kollontai (1982) é demonstrar como a gama de tarefas e produtos que eram executados pelas mulheres foram paulatinamente substituídos pelos trabalhos manufaturados.

Contudo, essas condições geraram outra contradição. Para Kollontai (1982, p. 50) "o capitalismo pôs nos ombros da mulher uma carga que a esmaga, fez dela uma assalariada, sem ter diminuído o seu trabalho de dona de casa e de mãe". Ela problematiza que a inserção das mulheres no mercado de trabalho e sua consequente ausência do espaço doméstico provocou uma degradação do padrão de vida das famílias, tal como Engels aponta em A situação da classe trabalhadora na Inglaterra, obra publicada em 1845.

Por isso, Kollontai (1982) defende a necessidade de socialização e responsabilização do Estado e da sociedade para com as tarefas originalmente vinculadas às famílias, especialmente as tarefas domésticas. Ela defende, ainda, a necessidade de se construírem cozinhas e restaurantes comunitários, lavandarias, escolas públicas etc., problematizando que alguns desses equipamentos, embora já existissem nos grandes centros capitalistas, não eram destinados às famílias trabalhadoras. Em suma, a questão do ócio e do tempo livre é essencial para pensar a libertação das mulheres da sua histórica subordinação.

Mesmo diante da abolição das leis que legitimavam a inferioridade das mulheres, elas continuaram sendo escravas domésticas, já que estavam presas a uma mesquinha economia doméstica que embrutece e oprime. Para Lenin (1919a, p. 2)

A verdadeira emancipação da mulher, o verdadeiro comunismo, só começará onde e quando comece a luta das massas (dirigida pelo 
proletariado, que detém o poder do Estado), contra a pequena economia doméstica, ou melhor, onde comece a transformação em massa dessa economia na grande economia socialista.

Embora já existissem, nos países capitalistas, experiências de creches e restaurantes populares, na URSS estes equipamentos estão atrelados a uma perspectiva de emancipação das mulheres a partir da socialização do trabalho doméstico.

Sensível à luta e aos direitos das mulheres, Lenin participava de vários encontros das mulheres operárias, sempre procurando reconhecer os avanços, os limites e, sobretudo, os desafios postos à organização dessas mulheres para o triunfo da revolução. Em pronunciamento realizado na Conferência das mulheres operárias, Lenin (1980) expôs algumas tarefas gerais que ele julga serem necessárias para atuação das mulheres operárias. Contudo, ele fazia uma crítica acerca do modo como a revolução estava lidando com o papel que cumpre a essas iniciativas, como, por exemplo, as dificuldades de a imprensa soviética divulgar e mostrar a importância dos restaurantes populares e creches.

Lenin (1980) afirmou que o poder soviético enfrentou desde o início a questão da subalternidade das mulheres. Para ele, todo Estado operário que vislumbre a construção do socialismo também deverá cumprir essa tarefa. A questão inicial é abolir as legislações que institucionalizam a subalternidade feminina.

Lenin (1980) ressaltou que os Estados democráticos europeus mais avançados não foram capazes de avançar com relação aos direitos das muIheres. Esta afirmação reside na premissa de que, onde há capitalismo, há privilégios para os homens. Desse modo, tais democracias são simultaneamente incapazes de subverter tanto a miséria do operariado quanto a condição de dupla escravidão das mulheres. Para Lenin (1919b, p. 2), "[...] o poder soviético, como poder dos trabalhadores, realizou nos primeiros meses de sua existência, a reviravolta mais decisiva na legislação sobre a mulher".

Contudo, o próprio Lenin (1980) apontava que só alterar a legislação não é suficiente, pois estas mudanças são apenas o começo. Para ele, um passo decisivo na construção da igualdade entre homens e mulheres é a socialização do trabalho doméstico. Este trabalho, portanto, deveria ser responsabilidade do Estado para que as mulheres pudessem participar, assim como os homens, do trabalho produtivo geral. Dirigindo-se às mulheres trabalhadoras, ele afirma que:

Todas vós sabeis que, mesmo quando existe plena igualdade de direitos, essa opressão da mulher continua de fato a subsistir, porque sobre ela cai todo o peso do trabalho doméstico que, na maior parte dos casos, é o trabalho menos produtivo, mais pesado, mais bárbaro. É um trabalho extremamente mesquinho que não pode contribui, no 


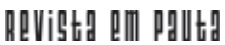

\} REFLEXÕES LENINISTAS SOBRE O ESTADO E A LUTA DAS MULHERES - ALVES, L. N. \}

DOI: $10.12957 /$ REP.2016.27841

mínimo que seja, para o desenvolvimento da mulher. (LENIN, 1919b, p. 4).

Nesta direção, Lenin (1980) reconheceu que o início do socialismo na República Soviética depende da completa libertação das mulheres do trabalho doméstico, ou seja, da sua condição de escravas domésticas. Para isso, apontou a necessidade de se construir um conjunto de equipamentos públicos, como refeitórios e creches, que contribuam neste processo.

Lenin (1980) também empreendeu uma crítica à baixa participação das mulheres na política, inclusive naquelas sociedades mais avançadas e "democráticas", sendo uma tarefa da revolução socialista tornar a vida pública/política acessível às mulheres. Ao mesmo tempo, Lenin (1980) percebeu que este movimento deve estar acompanhado de uma inserção das mulheres em distintos ramos, tais como no exército vermelho, nas fazendas agrícolas experimentais, na construção de restaurantes, no abastecimento e distribuição de alimentos etc.

Num pronunciamento cujo tema era $O$ poder soviético e a situação da mulher, Lenin (1919c) buscou mostrar como o poder soviético e o capitalismo incorporaram a "questão da mulher". Para ele, as acusações de que o poder soviético solapou a democracia são equivocadas, pois o grande feito da revolução foi ampliar a democracia para a grande maioria explorada. A democracia construída com a Revolução Russa é a democracia da ampla maioria do povo.

Um aspecto que particulariza a diferença entre a democracia socialista e a democracia burguesa é a posição das mulheres nessas duas sociedades. Em nenhuma república burguesa as mulheres gozavam de plena igualdade jurídica. Liberdade e igualdade entre homens e mulheres eram (e ainda são) inviáveis na democracia burguesa. Nas palavras de Lenin (1919c, p. 3):

Em dois anos, em um dos países mais atrasados da Europa, o poder soviético fez pela emancipação da mulher, por sua igualdade com o sexo 'forte', mais do que haviam feito todas as repúblicas avançadas, cultas, 'democráticas' do mundo inteiro, no curso de cento e trinta anos.

Para Lenin (1980), o domínio do capital e os vícios burgueses impediram estas repúblicas "democráticas" de avançarem em relação aos direitos das mulheres como, por exemplo, na reformulação da legislação opressora vigente em relação ao casamento, divórcio etc.

Diante do crescimento da participação das mulheres nas eleições soviets para deputados operários de Moscou, Lenin (1920a) diz, em carta Às operárias, que o poder soviético foi o primeiro a abolir legislações que legitimavam a subalternidade das mulheres. Ele citou o exemplo da legis- 


\section{hevistg aाm pguttg}

\} REFLEXÕES LENINISTAS SOBRE O ESTADO E A LUTA DAS MULHERES - ALVES, L. N. \}

DOI: $10.12957 /$ REP.2016.27841

lação que privilegiava o homem na esfera do direito matrimonial e as vantagens que garantiam ao homem o acesso à propriedade. "Onde existem latifundiários, capitalistas e comerciantes, não pode existir a igualdade entre o homem e a mulher, nem mesmo diante da lei" (LENIN, 1920a, p. 1).

Contudo, para a construção da igualdade entre homens e mulheres na República Soviética não bastava a igualdade perante a legislação. Para Lenin (1920a), era necessária a igualdade de fato; inclusive, deve-se garantir a participação das mulheres na gestão das empresas públicas e na administração do Estado. Desse modo, Lenin (1920a) explicitou a necessidade de ampliação da participação das mulheres na política, independentemente de serem das fileiras de seu próprio partido. Em suas próprias palavras,

Elegei, portanto, para o Soviete um maior número de operárias, tanto como comunistas como sem partido. Desde que uma operária seja honesta, conscienciosa e dê bom rendimento no trabalho, que importa que não pertença ao partido? Elegei-a para o Soviete de Moscou! Mais operárias para o Soviete de Moscou! Demonstre o proletariado moscovita que está disposto a fazer tudo, e que tudo faz para lutar até a vitória, para lutar contra a velha desigualdade, contra o antigo aviltamento burguês da mulher! (LENIN, 1920a, p. 2).

Em suma, Lenin (1920a) afirmou que o proletariado não alcançará a emancipação completa se não for conquistada, primeiro, a total emancipação das mulheres.

Outro aspecto fundamental da Revolução de outubro, caracterizado por Lenin (1921), consiste na capacidade e necessidade de atrair setores da população oprimidos pelo capitalismo. Destarte, não é possível atrair as massas para a política sem atrair as mulheres. Na sociedade burguesa, as mulheres vivenciam desigualdades em relação aos homens, tanto pela legislação quanto pela escravidão doméstica.

O primeiro passo da revolução foi abolir toda legislação que legitima a subalternidade das mulheres. O segundo passo consistiu na abolição da propriedade privada das terras, das fábricas e usinas. Para Lenin (1921, p. 2), "essa abolição, e somente ela, abre caminho para a emancipação completa e efetiva da mulher, para sua libertação da 'escravidão doméstica', porque assinala a passagem da mesquinha e fechada economia doméstica para a grande economia socializada". Ele ressaltou que essa transição não é fácil, pois implica desconstruir relações de opressão arcaicas que enrijecem a sociedade.

Neste sentido, percebemos que Lenin (1980) via que o avanço das reivindicações feministas dependia do vigor da Revolução Russa, mas, simultaneamente, afirmava que a consolidação do processo revolucionário dirigido pelos trabalhadores dependia da ampla mobilização das mulheres e da garantia dos seus direitos. 


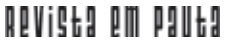

\} REFLEXÕES LENINISTAS SOBRE O ESTADO E A LUTA DAS MULHERES - ALVES, L. N. \}

DOI: $10.12957 /$ REP.2016.27841

A perspectiva de construção do comunismo visando superar as amarras da sociabilidade capitalista também deveria extinguir as formas de dominação das mulheres. É nesta direção que Lenin (1980) buscou guiar os rumos do início da revolução. Contudo, os rumos tomados pela revolução não foram os mesmos assumidos publicamente. Goldman (2014) percebe, inclusive, que os compromissos libertários em relação às mulheres e à família foram paulatinamente abandonados.

Por hora, cabe ressaltar que o legado do feminismo socialista e o compromisso político de Lenin com a luta das mulheres permanecem válidos e necessários na conjuntura atual de avanço do conservadorismo. Na América Latina, por exemplo, é comum entre os movimentos sociais, notadamente os de esquerda, a assunção desse leito histórico, bem como o fato de eles se guiarem a partir dessa inspiração libertária.

\section{Considerações finais}

Ao retomar as contribuições de Lenin e do feminismo socialista, estamos nos propondo a realizar uma interlocução com sujeitos históricos que formularam teoricamente e empreenderam um esforço vital para transformar a realidade que vivenciavam. Lenin $(1980 ; 2010 ; 2015)$, ao recuperar o legado de Marx e Engels e lutar contra a sua vulgarização, revigorou a assertiva marxiana de que cabe ao proletariado levar a revolução até o fim para destruir o modo de vida capitalista.

Sem dúvidas, Lenin contribuiu (e contribui) para formulação estratégica e tática de amplos setores progressistas que assumem distintas trincheiras, seja por meio da luta política e/ou pela batalha das ideias.

Tendo em vista o esforço de Lenin (2010) em particularizar o universal e universalizar o particular, faz-se necessário demarcar a atualidade de seu pensamento e de sua concepção de Estado. Ao recuperar a elaboração marxiana de que o Estado é um aparato de dominação de uma classe, Lenin (2010) não escamoteou o papel que o Estado cumpre na dominação dos trabalhadores. Ao contrário, percebendo que o Estado concentra o poder de uma classe que hegemoniza a sociedade, ele buscou traçar o papel e os desafios da classe operária para alçar a revolução socialista.

Neste sentido, Lenin partiu de uma caracterização do Estado nas condições históricas da Rússia e, à luz da correlação de forças das classes sociais, percebeu a via da tomada do poder do Estado como condição para o triunfo da revolução. Esse exercício influenciou grande parte da esquerda no mundo inteiro, apesar dos equívocos e das leituras mecânicas que aconteceram ao longo do século XX.

Lenin (2010) também ressaltou o papel da violência revolucionária, tendo em vista que tomar o poder do Estado implica um jogo de interesses que não é pacífico nem harmônico. Esse aspecto, em alguma 


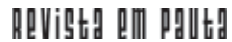

\} REFLEXÕES LENINISTAS SOBRE O ESTADO E A LUTA DAS MULHERES - ALVES, L. N. \}

DOI: $10.12957 /$ REP.2016.27841

medida, ainda é um tabu na esquerda, que sofre com os rebatimentos do fim da União Soviética.

Por fim, destaca-se a perspectiva do definhamento do Estado e, consequentemente, o definhamento do modo de vida capitalista, pois esse processo implica destruir as relações de classe. É, portanto, um aspecto fundamental para o diálogo com o feminismo socialista e com as reivindicações das mulheres. Para garantir êxito na construção de condições históricas para o definhamento do Estado, é necessário rever o papel da família e a posição que homens e mulheres ocupam na sociedade. Para isso, foi importante que a Revolução se colocasse na dianteira desse processo, extinguindo leis que legitimavam a dominação das mulheres, ampliando a participação destas nos espaços políticos e no exercício do poder, afinal, era necessário "construir o socialismo com os homens que foram educados, apodrecidos e corrompidos pelo capitalismo, mas que, precisamente desse modo, também foram preparados por ele para a luta" (LENIN apud LUKÁCS, 2012, p. 56).

Em suma, a Revolução de outubro de 1917 vislumbrava uma verdadeira transformação que incorporava os desafios da construção efetiva de igualdade entre os sexos. Essa visão libertária das contradições de classe e gênero permanece como inspiração para edificar uma práxis em busca de uma sociedade efetivamente livre, onde não existam classes sociais e exploração/dominação de gênero. Após 100 anos da Revolução Russa, estes desafios permanecem atuais e interroga toda a geração que a projeta a possibilidade de vivenciarmos relações efetivamente humanas e livres. 


\section{Referências}

ALVES, B. M.; PITANGUY, J. O que é feminismo? São Paulo: Abril Cultural, 1985.

BRAZ, M. Apresentação a "Que Fazer?". In: LENIN, V. Que Fazer? Problemas candentes do nosso movimento. São Paulo: Expressão Popular, 2015.

CHEVALLIER, J.-J. As grandes obras políticas: de Maquiavel a nossos dias. Rio de Janeiro: Agir, 1973.

ENGELS, F. A origem da família, da propriedade privada e do Estado. São Paulo: Expressão Popular, 2010.

GOLDMAN, W. Mulher, Estado e revolução: política familiar e vida social soviética. São Paulo: Boitempo; Iskra Edições, 2014.

GONZÁLEZ, A. I. A. As origens e a comemoração do dia internacional das mulheres. São Paulo: Expressão Popular, 2010.

GURGEL, T. Feminismo e luta de classe: a auto-organização das mulheres pela história. In: Caderno de debates: a consulta popular e o feminismo. São Paulo: Consulta Popular, 2009.

. Feminismo e luta de classe: história, movimento e desafios teóricopolíticos do feminismo na contemporaneidade. In: 9o SEMINÁRIO INTERNACIONAL FAZENDO GÊNERO. Anais... Florianópolis, 2010.

KOLONTAI, A. A família e o Estado socialista. In: MACHEL, S. et al. A libertação da mulher. São Paulo: Global, 1982.

LENIN, V. A contribuição da mulher na construção do socialismo. 1919a. Disponível em: <https://www.marxists.org>. Acesso em: 15 de setembro de 2015.

- As tarefas do movimento operário feminino na República dos Soviets. 1919b. Disponível em: <https://www.marxists.org>. Acesso em: 15 de setembro de 2015.

. O poder soviético e a situação da mulher. 1919c. Disponível em: <https://www.marxists.org>. Acesso em: 15 de setembro de 2015.

Às operárias. 1920a. Disponível em: <https://www.marxists.org>. Acesso em: 15 de setembro de 2015.

. O dia internacional da mulher. 1920b. Disponível em: <https:// www.marxists.org >. Acesso em: 15 de setembro de 2015.

. O dia internacional das mulheres. 1921. Disponível em: <https:// www.marxists.org>. Acesso em: 15 de setembro de 2015.

Sobre a emancipação da mulher. São Paulo: Ed. Alfa-Omega, 1980. 


\section{hevigtg aाm pguttg}

\} REFLEXÕES LENINISTAS SOBRE O ESTADO E A LUTA DAS MULHERES - ALVES, L. N. \}

DOI: $10.12957 /$ REP.2016.27841

. O Estado e a Revolução: o que ensina o marxismo sobre o Estado e o papel do proletariado na revolução. São Paulo: Expressão Popular, 2010.

. Imperialismo, estágio superior do capitalismo. São Paulo: Ed. Expressão Popular, 2012.

. Que fazer: problemas candentes de nosso movimento. São Paulo: Expressão Popular, 2015.

LUKÁCS, G. Lenin: um estudo sobre a unidade de seu pensamento. Tradução de Rubens Enderle. São Paulo: Boitempo, 2012.

MONTAÑO, C.; DURIGUETTO, M. L. Estado, classe e movimento social. São Paulo: Cortez, 2011.

ZETKIN, C. O sufrágio feminino. Discurso pronunciado na Conferência de Mulheres Socialistas, Mannheim, 1906. In: GONZÁLEZ, A. I. A. As origens e a comemoração do dia internacional das mulheres. São Paulo: Expressão Popular, 2010.

Recebido em 31 de julho de 2016.

Aprovado para publicação em 22 de novembro de 2016. DOI: 10.12957/rep.2016.27841

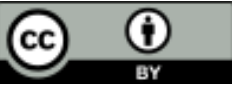

A Revista Em Pauta: Teoria Social e Realidade Contemporânea está licenciada com uma Licença Creative Commons Atribuição 4.0 Internacional. 